\title{
Jurist-Diction
}

Volume 4 No. 2, Maret 2021

\section{Dewan Pengawas Dalam Undang-Undang Nomor 19 Tahun 2019 Tentang Perubahan Kedua Atas Undang-Undang Nomor 30 Tahun 2002}

\author{
Cris Septiani \\ cris.septiani-2016@fh.unair.com \\ Universitas Airlangga
}

How to cite:

Cris Septiani 'Dewan

Pengawas Dalam Undang-

Undang Nomor 19 Tahun 2019

Tentang Perubahan Kedua Atas

Undang-Undang Nomor 30

Tahun 2002' (2021) Vol. 4 No.

2 Jurist-Diction.

Histori artikel:

Submit 9 Januari 2021;

Diterima 18 Februari 2021;

Diterbitkan 1 Maret 2021.

DOI:

10.20473/jd.v4i2.25755

p-ISSN: $2721-8392$

e-ISSN: $2655-8297$

\section{Abstract}

This research aims to analyse the changes in the substance contained in the Law No. 19 of 2019. One of them is the authority and independence owned by the Board of controler. The supervisory board is formed in order to implement its function, which is to supervise the duties and authorities of KPK. The authority of the Board of controler is mentioned in article $37 \mathrm{~B}$. In the authority of the supervisory board which should be the supervisor but has the function of Pro Justitia which should be owned by law enforcement officers. The pro Justitia functions owned by the Board of controler are the granting of permit tapping, search and seizure. The authority owned by the Board of controler is assessed to weaken and restrict KPK's space in dealing with corruption crimes. In addition, public concerns about the permission of intercepts to the supervisory board that is prone to leakage and making bureaucracy become long. In addition, the independence of the Board of controler as a KPK supervisor is also a question.

Keywords: Board of Controler; Authority; Independence; Law No. 19 of 2019.
Abstrak
Penelitian ini bertujuan untuk menganalisis perubahan substansi yang terdapat dalam Undang-Undang Nomor 19 Tahun 2019. Salah satunya kewenangan serta independensi yang dimiliki oleh Dewan Pengawas. Dewan Pengawas dibentuk dalam rangka untuk melaksanakan fungsinya yaitu mengawasi pelaksanaan tugas dan wewenang KPK. Kewenangan Dewan Pengawas disebutkan dalam Pasal 37 B. Dalam kewenangan tersebut Dewan Pengawas yang seharusnya menjadi pengawas tetapi memiliki fungsi Pro Justitia yang harusnya dimiliki oleh Aparat Penegak Hukum. Fungsi pro justitia yang dimiliki oleh Dewan Pengawas adalah pemberian izin penyadapan, penggeledahan dan penyitaan. Kewenangan yang dimiliki oleh Dewan Pengawas dinilai melemahkan dan membatasi ruang gerak KPK dalam menangani Tindak Pidana Korupsi. Selain itu kekhawatiran publik mengenai izin penyadapan kepada Dewan Pengawas yang rawan adanya kebocoran serta membuat birokrasi menjadi panjang. Selain itu independensi Dewan Pengawas sebagai pengawas KPK juga menjadi pertanyaan.
Kata Kunci: Dewan Pengawas; kewenangan; independensi; UU Nomor 19 Tahun 2019. 


\section{Pendahuluan}

Komisi Pemberantasan Korupsi (KPK) dibentuk berdasarkan UndangUndang Nomor 30 tahun 2002 tentang Komisi Pemberantasan Tindak Pidana Korupsi. Pada perkembangannya Undang-Undang yang mengatur tentang Komisi Pemberantasan Korupsi (KPK) ini telah diubah menjadi Undang-Undang Nomor 19 Tahun 2019 tentang Perubahan Kedua Atas Undang-Undang Nomor 30 Tahun 2002 tentang Komisi Pemberantasan Tindak Pidana Korupsi. Diundangkannya Undang-Undang Nomor 19 Tahun 2019, banyak terdapat pertentangan yang menjadi perdebatan dengan adanya perubahan terhadap substansi dari UndangUndang tersebut.

Terdapat perubahan Stuktur organisasi KPK, Berdasarkan Pasal 21 UndangUndang Nomor 30 Tahun 2002 tentang Komisi pemberantasan tindak pidana korupsi, Komisi Pemberantasan Korupsi terdiri atas :

a. Pimpinan Komisi Pemberantasan Korupsi yang terdiri dari 5 (lima) Anggota Komisi Pemberantasan Korupsi;

b. Tim Penasihat yang terdiri dari 4 (empat) Anggota; dan

c. Pegawai Komisi Pemberantasan Korupsi sebagai pelaksana tugas.

Dalam Undang-Undang Nomor 19 Tahun 2019, Struktur organisasi KPK terdapat penambahan organ baru, disebutkan dalam Pasal 21 Komisi Pemberantasan Korupsi terdiri atas :

a. Dewan Pengawas yang berjumlah 5 (lima) orang;

b. Pimpinan Komisi Pemberantasan Korupsi yang terdiri dari 5 (lima) orang Anggota KomisiPemberantasan Korupsi; dan

c. Pegawai Komisi Pemberantasan Korupsi

Berdasarkan penjelasan Undang-Undang Nomor 19 Tahun 2019 yang menunjukkan mendukung adanya Dewan Pengawas karena diperlukan adanya pembaharuan hukum agar dalam pencegahan dan pemberantasan tindak pidana korupsi berjalan dengan efektif dan terpadu. Dibentuknya Dewan Pengawas ini untuk mengawasi serta mengontrol pelaksanaan tugas dan wewenang KPK 
sehingga dapat mengurangi adanya penyalahgunaan wewenang. ${ }^{1}$ Dewan Pengawas diharapkan dapat mengevaluasi dan meningkatkan upaya pemberantasan tindak pidana korupsi serta untuk mengurangi potensi dan mencegah terjadinya abuse of power atau penyalahgunaan wewenang oleh pimpinan KPK.

Pertentangan substansi dalam Undang-Undang Nomor 19 Tahun 2019, salah satunya mengenai pembentukan Dewan Pengawas. Berdasarkan Pasal 37A ayat (1) Undang-Undang Nomor 19 Tahun 2019, bahwa Dewan Pengawas dibentuk dalam rangka untuk melaksanakan fungsinya yaitu mengawasi pelaksanaan tugas dan wewenang Komisi Pemberantasan Korupsi (KPK). Dewan Pengawas memiliki tugas dan kewenangan Pada Pasal 37 B Undang-Undang Nomor 19 Tahun 2019, kewenangan tersebut diantaranya:

a. Mengawasi pelaksanaan tugas dan wewenang Komisi Pemberantasan Korupsi;

b. Memberikan izin atau tidak memberikan izin Penyadapan, penggeledahan, dan/ atau penyitaan;

c. Menyusun dan menetapkan kode etik Pimpinan dan Pegawai Komisi Pemberantasan Korupsi;

d. Menerima dan menindaklanjuti laporan dari masyarakat mengenai adanya dugaan pelanggaran kode etik oleh Pimpinan dan Pegawai Komisi Pemberantasan Korupsi atau pelanggaran ketentuan dalam Undang-Undang ini;

e. Menyelenggarakan sidang untuk memeriksa adanya dugaan pelanggaran kode etik oleh Pimpinan dan Pegawai Komisi Pemberantasan Korupsi; dan

f. Melakukan evaluasi kinerja Pimpinan dan Pegawai Komisi Pemberantasan Korupsi secara berkala 1 (satu) kali dalam 1 (satu) tahun.

Berdasarkan pasal diatas, pembentukan Dewan Pengawas mempunyai kewenangan yang lebih besar sehingga dapat melemahkan kewenangan yang dimiliki oleh KPK dimana kewenangan yang dimiliki Dewan Pengawas melampaui batasan pengawasan. $^{2}$ Dalam pasal tersebut menunjukkan bahwa Dewan Pengawas melakukan pengaturan terhadap pelaksanaan tindakan yang dilakukan oleh KPK dan memiliki fungsi Pro Justitia. Penolakan adanya Dewan Pengawas dikarenakan

\footnotetext{
1 Undang-Undang Nomor 19 Tahun 2019 tentang Perubahan Kedua Atas Undang-Undang Nomor 30 Tahun 2002 tentang Komis Pemberantasan Tindak Pidana Korupsi.

2 Aida Mardatillah, 'Kewenangan Dewan Pengawas KPK Disebut Lampaui Batas Pengawasan', (Hukum Online, 2019) < https:/www.hukumonline.com/berita/baca/lt5daea72d91232/ kewenangan-dewan-pengawas-kpk-disebut-lampaui-batas-pengawasan/> accessed 16 November 2019.
} 
salah satunya Dewan Pengawas sebagai pengawas dan bukan aparat penegak hukum memiliki fungsi Pro Justitia yaitu memiliki kewenangan untuk memberikan izin penyadapan, penggeledahan dan penyitaan. Selain itu diperlukannya izin untuk melakukan penyadapan dalam penanganan Tindak Pidana Korupsi dapat mempersempit ruang KPK dan memperpanjang birokrasi yang dapat mengakibatkan proses tersebut menjadi berlarut-larut.

Pengawasan organ Anti Korupsi di Negara lain seperti CPIB Singapura dan ICAC Hongkong tidak ditemukan pengawas internal yang mempunyai kewenangan seperti Dewan Pengawas. Terdapat pengawas internal dan pengawas eksternal. Dalam pengawas internal pada lembaga kejaksaan yang dilakukan oleh Jaksa Agung Muda Pengawasan. Dimana dalam pengawasan yang dilakukan oleh Jaksa Agung Muda Pengawasan sebagai pengawas internal tidak terdapat kewenangan seperti yang dimiliki oleh Dewan Pengawas. Selain itu organ pengawas dalam sistem peradilan pidana terdapat lembaga pengawas eksternal seperti Komisi kejaksan, Komisi yudisial untuk mekanisme check and balances pengawasan internal suatu lembaga tersebut. Dibentuknya lembaga KPK ini dicita-citakan sebagai lembaga trigger mechanism yang mana berfungsi sebagai pemicu dan pemberdaya institusi yang telah ada dalam pemberantasan tindak pidana korupsi sehingga dapat berjalan lebih efektif dan efisien.

Perubahan pada UUD NRI Tahun 1945 telah berimplikasi terhadap struktur organisasi negara, termasuk bentuk serta fungsi Lembaga-lembaga Negara. Lembaga tersebut dapat dibedakan ke dalam tiga lapis. Organ-organ tersebut antara lain lembaga tinggi Negara sebagai organ lapis pertama, lembaga Negara sebagai Organ lapis kedua, dan lembaga daerah sebagi organ lapis ketiga. Lembaga-lembaga tersebut dikategorikan sebagai organ utama atau primer (primary constitusional organs) dan organ pendukung atau penunjang (state auxiliary bodies). ${ }^{3}$ Lembaga pendukung atau penunjang (state auxiliary bodies) tersebut berupa lembaga-

\footnotetext{
3 Aulia Rahmat, 'Urgensi Pengawasan Terhadap Komisi Pemberantasan Korupsi Republik Indonesia Dalam Struktur Ketatanegaraan Indonesia’ (Program Sarjana Universitas Islam Indonesia 2018).[4].
} 
lembaga negara baru seperti Dewan (council), Komisi (commission), Komite (committee), Badan (board), atau Otoritas (authority). ${ }^{4}$

Pada umumnya pembentukan lembaga-lembaga independen ini didorong oleh kenyataan birokrasi di lingkungan pemerintahan dinilai tidak dapat lagi memenuhi kebutuhan akan pelayanan umum dengan standar mutu yang semakin meningkat dan diharapkan semakin efisien dan efektif. Adapun salah satu lembaga negara bantu yang bersifat penunjang adalah KPK. Lahirnya lembaga independen ini merupakan bentuk ketidakpercayaan terhadap lembaga-lembaga yang telah ada dimana lembaga independen ini berfungsi sebagai pengawas lembaga yang telah ada. Seperti terbentuknya KPK yang kemudian menjadi lembaga independen dikarenakan hilangnya kepercayaan masyarakat terhadap lembaga penegak hukum yang telah ada sebelumnya.

Adanya pembaharuan hukum pada undang-undang yang mengatur tentang KPK ini, dimana mengatur tindakan yang akan dilakukan oleh KPK dalam melakukan pemberantasan dalam Tindak Pidana Korupsi harus berdasakan atas izin Dewan Pengawas yang mengakibatkan KPK sulit dalam melaksanakan tugas, oleh karena itu independensi KPK juga dipertanyakan. Selain itu dikarenakan Dewan pengawas juga mempunyai kewenangan yang besar serta termasuk dalam struktur organisasi internal KPK maka keindependensian Dewan Pengawas juga dipertanyakan. Dewan Pengawas yang memiliki kewenangan yang besar juga dipertanyakan lembaga yang akan mengawasi nantinya.

\section{Fungsi dan Kewenangan Dewan Pengawas dalam Pasal 37 B Undang-Undang Nomor 19 Tahun 2019}

Dalam pasal yang telah disampaikan diatas, Dewan Pengawas memiliki fungsi yang dituangkan dalam Pasal 37 A ayat (1) menyatakan bahwa Dewan Pengawas dibentuk dalam rangka untuk mengawasi pelaksanaan tugas dan wewenang Komisi Pemberantasan Korupsi (KPK) dalam penanganan dan pencegahan Tindak Pidana

\footnotetext{
${ }^{4}$ Josef M. Monteiro, 'Penempatan Komisi Pemberantasan Korupsi Sebagai Organ UndangUndang Dasar Negara RI Tahun 1945’, (2012) 02 Jurnal Hukum Dan Pembangunan. [287].
} 
Korupsi. Dewan Pengawas dibentuk diharapkan untuk mengawasi kinerja Komisi Pemberantasan Korupsi (KPK) agar menjalankan fungsi dan Kewenangannya sesuai dengan Peraturan Perundang-Undangan yang ada.

Pada pasal 37 B huruf a, Dewan Pengawas memiliki tugas untuk mengawasi pelaksanaan tugas dan wewenang Komisi Pemberantasan Korupsi. Tugas komisi pemberantasan korupsi terdapat dalam Pasal 6 Undang-Undang Nomor 19 Tahun 2019, diantaranya melaksanakan pemberantasan Tindak Pidana Korupsi dengan melakukan koordinasi dengan instansi lain yang berwenang, melakukan tindakan-tindakan pencegahan Tindak Pidana Korupsi, monitor terhadap penyelenggaraan pemerintahan Negara, melakukan penyelidikan, penyidikan dan penuntutan, serta melakukan tindakan untuk melaksanakan penetapan hakim dan putusan yang memiliki kekuatan hukum tetap. Dewan Pengawas dalam hal ini tidak hanya mengawasi kerja KPK, menetapkan kode etik, evaluasi tugas pimpinan dan anggota KPK setahun sekali, hingga menyerahkan laporan evaluasi kepada presiden dan DPR tetapi juga memberikan izin terhadap penyadapan, penggeledahan, serta penyitaan. Hal tersebut yang kemudian menjadi permasalahan, Dewan Pengawas seperti membatasi ruang gerak komisi pemberantasan korupsi dalam melakukan tugasnya. ${ }^{5}$

Dalam Undang-Undang 30 Tahun 2002 terdapat Pengawas Internal yang mengawasi tentang dugaan pelanggaran kode etik, evaluasi kinerja yang dilakukan oleh Pimpinan dan Pegawai KPK. Pengawasan internal diatur lebih lanjut dalam Pasal 48 Peraturan Komisi Pemberantasan Korupsi Nomor 03 Tahun 2018 Tentang Organisasi Dan Tata Kerja Komisi Pemberantasan Korupsi. Direktorat pengawasan internal.

Dewan Pengawas memiliki tugas untuk memberikan izin atau tidak memberikan izin Penyadapan, penggeledahan, dan/atau penyitaan yang dinyatakan dalam Pasal 37 B huruf b Undang-Undang Nomor 19 Tahun 2019. Pengawasan

\footnotetext{
5 Andry Novellino, 'Dewan Pengawas Dan Segudang Curiga Intervensi Pada KPK', (CNN Indonesia, 2019), <Https:/Www.Cnnindonesia.Com/Nasional/20190920204301-32-432456/Dewan-Pengawas-Dan-Segudang-Curiga-Intervensi-Pada-Kpk>, accesed 29 Maret 2020.
} 
pada KPK saat ini yang dilakukan oleh Dewan Pengawas bukan hanya sekedar pengawasan terhadap Kode etik dan evaluasi kinerja Pimpinan dan Pegawai KPK, tetapi Dewan Pengawas mempunyai kewenangan diluar sistem pengawasan, yaitu dengan memberikan atau tidak memberikan izin penyadapan, penggeledaan dan penyitaan. ${ }^{6}$ Melakukan izin penyadapan, penggeledahan dan penyitaan termasuk dalam fungsi pro justitia. Fungsi Pro Justitia ini menunjukkan bahwa tindakan yang diambil oleh aparat penegak hukum adalah tindakan hukum yang sah dan memiliki kekuatan hukum mengikat. ${ }^{7}$ Dewan Pengawas dalam Pasal 37 B Undang-Undang Nomor 19 Tahun 2019 memiliki kewenangan Pro justitia. Kewenangan tersebut diantaranya adalah memberikan izin penyadapan, penggeledahan dan penyitaan dimana kewenangan tersebut termasuk dalam fungsi Pro Justitia sehingga lembaga pemberi izinnya harus lembaga yang melakukan fungsi Pro Justitia yaitu Aparat Penegak Hukum. ${ }^{8}$ Dalam pelaksanaan tugas Dewan Pengawas KPK menggantikan peran dan fungsi peradilan terutama berkaitan dengan keseluruhan proses penegakan hukum diantaranya meliputi penyadapan, penggeledahan dan penyitaan, dimana Dewan Pegawas fungsinya bukan sebagai bagian dari penegakan hukum dalam criminal justice system. ${ }^{9}$ Penyadapan yang dilakukan oleh KPK sebelum berlakunya Undang-Undang Nomor 19 Tahun 2019, diatur dalam Pasal 12 ayat (1) huruf a Undang-Undang Nomor 30 tahun 2002 yang kemudian diatur melalui Peraturan KPK Nomor 7 Tahun 2015 mengenai Audit Penyadapan Informasi yang Sah (Lawful Interception). Dalam Undang-Undang Nomor 19 Tahun 2019, memasukan beberapa ketentuan/ pengaturan baru mengenai penyadapan oleh KPK yang terdapat dalam Pasal 12B, Pasal 12B ayat (4), Pasal 12C dan Pasal 12D mengenai permohonan izin oleh Dewan Pegawas, Jangka waktu penyadapan, pelaporan penyadapan dan hasil penyadapan.

\footnotetext{
${ }^{6}$ ibid.

7 Arif Maulana, 'Apa itu pro justitia?' (Hukum Online, 2019), < https://www.hukumonline. com/klinik/detail/ulasan/lt5e006f96d6231/apa-itu-ipro-justitia-i/> accesed 24 Desember 2020.

8 ibid.

9 Agus Suntoro, 'Penyadapan Dan Eksistensi Dewan Pengawas Komisi Pemberantasan Tindak Pidana Korupsi' (2020) 17 Jurnal Legislasi Indonesia.[35].
} 
Pengawasan yang dilakukan oleh lembaga-lembaga Negara yang dalam melaksanakan tugas dan fungsinya melakukan pembatasan hak asasi manusia termasuk dalam penyadapan yang dilakukan oleh KPK maka seharusnya mendapatkan pengawasan yang dilakukan oleh 3 (tiga) elemen yaitu Parlemen, Badan Peradilan dan Badan Independen. ${ }^{10}$ Sistem peradilan pidana (criminal justice system) meletakan pengawasan dan perizinan penyadapan kepada badan peradilan adalah kondisi yang paling ideal selain itu perizinan dan pengawasan penyadapan yang dilakukan oleh aparat penegak hukum bertujuan untuk menjamin prinsip Check and Balances. Dalam hal ini Dewan Pengawas jika dilihat secara struktur organisasi KPK termasuk dalam bagian internal KPK, maka pengawasan yang dilakukan oleh Dewan Pengawas tidak menjamin adanya prinsip Check and Balances.

Kewenangan Dewan Pengawas dalam Pasal 37B Undang-Undang Nomor 19 Tahun 2019, menjadi kekhawatiran publik karena adanya upaya pelemahan terhadap KPK dalam melaksanakan tugas dan funginya dalam memberantas tindak pidana korupsi. Kekhawatiran tersebut dikarenakan tindakan yang akan dilakukan oleh KPK nantinya tergantung dan melekat pada Dewan Pengawas KPK, tidak lagi melekat pada pimpinan KPK. Pimpinan KPK dalam Pasal 21 ayat (4) Undang-Undang Nomor 30 Tahun 2002 merupakan penyidik dan penuntut umum. Tetapi dalam Undang-Undang Nomor 19 Tahun 2019, pasal terssebut telah diubah. Selain itu kekhawatiran publik lainnya mengenai izin penyadapan kepada Dewan Pengawas yang rawan adanya kebocoran dengan sifat limitatif, rahasia dan kecepatan penyadapan, maka perlu dibentuk independent body diluar KPK untuk mengawasi Dewan Pengawas. ${ }^{11}$

\section{Kedudukan Organ Pengawas dalam Sistem Peradilan Pidana}

Pelaksanan fungsi pemerintah dalam melakukan penyelenggaraan pemerintahan yang baik (Good Governance) juga diperlukan sistem pengawasan. Pengawasan memiliki peranan penting sebagai upaya untuk menghindari adanya
10 ibid.
11 ibid. 
kesalahan yang disengaja maupun tidak disengaja dan untuk menciptakan pemerintahan yang bersih, bertanggungjawab sehingga tujuan Negara dapat terwujud.Proses pengawasan terdiri dari beberapa fase yaitu menetapkan alat pengukur (standar), mengadakan penilaian (evaluate) dan mengadakan tindakan perbaikan (corrective action). ${ }^{12}$

Sistem pengawasan dalam hal ini memiliki dua bentuk yaitu pengawasan internal dan pengawasan eksternal. Pengawasan internal dan pengawasan eksternal ini dibentuk melalui peraturan perundang-undangan. Pengawasan internal merupakan pengawasan yang dilakukan oleh orang atau badan yang terdapat dalam lembaga yang bersangkutan. Pengawasan internal ini seperti yang terdapat pada lembaga kejaksaan yang diawasi oleh Jaksa Agung Muda Pengawasan dan pada lembaga Komisi Pemberantasan Korupsi terdapat pengawasan interal yaitu pada bagian bidang pengawasan internal dan pengaduan masyarakat. Pengawas eksternal merupakan pengawasan yang dilakukan oleh lembaga Organ pengawas dalam sistem peradilan pidana diantaranya terdapat lembaga seperti Komisi kejaksan, Komisi yudisial, Ombudsman, dan Komisi Pemberantasan Korupsi.

Dalam Tindak Pidana Korupsi terdapat lembaga Komisi Pemberantasan Korupsi dimana lembaga ini dibentuk karena ketidakpercayaan publik terhadap lembaga penegak hukum yang telah ada untuk menangani Tindak Pidana Korupsi. Komisi Pemerantasan Korupsi dicita-citakan sebagai Triggers Mechanism lembaga penegak hukum yang ada. Sebagai lembaga yang dicita-citakan sebagai Triggers Mechanism, Komisi Pemberantasan Korupsi dibentuk agar menjadi pemicu dan pemberdaya lembaga penegak hukum yang ada dalam menangani Tindak Pidana Korupsi. ${ }^{13}$ Dari fungsi Triggers Mechanism, dicerminkan oleh Komisi Pemberantasan Korupsi dalam tugasnya yang terdapat dalam Pasal 6 UndangUndang Nomor 30 Tahun 2002 yaitu dengan melakukan penindakan, pencegahan,

12 R Widyo Purmono, Pemberantasan Korupsi Dan Pidana Lainnya (Kompas Media Nusantara, 2016). [15].

13 Fahmi Ramadhan Firdaus, 'Keberadaan KPK dalam Upaya Pemberantasan Korupsi', (Hukum Online, 2019), <https://www.hukumonline.com/klinik/detail/ulasan/lt5ca466cb7f8ed/keberadaan-kpk-dalam-upaya-pemberantasan-korupsi/> , accesed 9 Januari 2020. 
koordinasi, supervisi dan monitoring terhadap instansi yang berwenang melakukan pemberantasan tindak pidana korupsi. ${ }^{14}$ Fungsi Triggers Mechanism dalam Komisi Pemberantasan Korupsi dijelaskan secara eksplisit dalam penjelesan Undang-Undang Nomor 30 Tahun 2002, bahwa dalam pemberantasan Tindak Pidana Korupsi, Komisi Pemberantasan Korupsi berfungsi sebagai pemicu dan pemberdaya institusi yang telah ada. Namun dalam Undang-Undang Nomor 19 Tahun 2019, tidak disebutkan secara eksplisit terdapat fungsi Triggers Mechanism, dalam penjelasan undang-undang tersebut menyebutkan bahwa kedudukan Komisi Pemberantasan Korupsi sebagai satu kesatuan aparatur lembaga pemerintah yang bersama-sama dengan kepolisian dan/atau kejaksaan melakukan upaya terpadu dan terstruktur dalam pencegahan dan pemberantasan korupsi serta melakukan kerjasama supervisi dan memantau institusi yang telah ada dalam upaya bersama melakukan pencegahan dan pemberantasan Tindak Pidana Korupsi.

Dalam Undang-Undang Nomor 19 Tahun 2019, Komisi Pemberantasan Korupsi memiliki organ baru dalam struktur organisasi yaitu Dewan Pengawas yang memiliki kewenangan untuk mengawasi Komisi Pemberantasan Korupsi. Dalam Komisi Pemberantsan Korupsi belum terdapat lembaga pengawasan eksternal. ${ }^{15}$ Tidak terdapat lembaga pengawas eksternal yang secara khusus mengawasi Komisi Pemberantasan Korupsi bukan berarti tidak ada pengawasan.

\section{Lembaga Negara Independen}

Pengertian dasar dari istilah 'independent' adalah adanya kebebasan, kemerdekaan, kemandirian, otonom (otonomi), tidak dalam dominasi personal maupun institusional. ${ }^{16}$ Independen dapat kita telusuri dari maknanya dalam Black law Dictionary disebutkan, "Independent: not dependent; not subject to control,

14 ibid.

${ }^{15}$ Tomi Marlin Manday, 'Studi Konseptual Mengenai Badan Pengawas Komisi Pemberantasan Korupsi’ (Program Sarjana Universitas Islam Negeri Syarif Hidayatullah Jakarta 2018).[7].

${ }^{16}$ Hendra N urtjahjo, 'Lembaga, Badan, Dan Komisi Negara Independen (State Auxiliary Agencies) Di Indonesia: Tinjauan Hukum Tata Negara’ (2005) 35 Jurnal Hukum Dan Pembangunan. [280]. 
restriction, modification, or limitation from a given outside source". ${ }^{17}$ Dalam Black law Dictionary disebutkan independen yang dimaksud berarti tidak tergantung, tidak tunduk pada control, pembatasan, modifikasi atau batasan dari pihak manapun. Berdasarkan pendapat Prof. Jimly Asshiddiqie, Independensi lembaga-Iembaga ini diperlukan untuk kepentingan menjamin pembatasan kekuasaan dan demokratisasi yang lebih efektif. ${ }^{18}$

Lembaga Negara independen adalah lembaga yang tidak memposisikan diri sebagai salah satu sari tiga lembaga kekuasaan sesuai trias politica dalam pelaksanaan fungsinya. ${ }^{19}$ Lembaga Negara independen juga disebut juga sebagai state auxiliary bodies atau bisa juga disebut sebagai lembaga penunjang. ${ }^{20}$ Pembentukan lembaga Negara independen dibentuk karena adanya ketidakpercayaan publik terhadap lembaga yang ada dalam menyelesaikan persoalan. Dibentuknya Lembaga Negara independen berfungsi untuk melakukan pengawasan dan menciptakan kelembagaan yang tepat dan sesuai dengan fungsinya serta untuk mengembalikan kepercayaan publik terhadap birokrasi terhadap lembaga-lembaga pemerintah yang konvensional karena dinilai tidak efektif dalam kinerjanya.

Lembaga independen umumnya bersifat membantu atau menunjang pelaksanaan kekuasaan negara tertentu. Independensi dapat dimaknai sebagai suatu yang tidak tergantung, bebas atau merdeka dari pengaruh lain, serta bukan bagian dari pemerintah. Sehingga lembaga yang independensi merupakan lembaga yang bebas dari pengaruh atau intervensi dari lembaga lain.

Komisi Pemberantasan Korupsi (KPK) merupakan lembaga Negara bantu atau penunjang yang bersifat independen dan bebas dari pengaruh kekuasaan manapun

17 Henry Campbell Black, Black's Law Dictionary With Pronunciations (ST. Paul, Minn, West Publishing Co 1983).[394].

18 Jimly Asshiddiqie, Pokok-Pokok Hukum Tata Negara Indonesia (BIP Kelompok Gramedia, 2008).[879].

${ }^{19}$ Zainal arifin mochtar, Lembaga Negara Independen (Rajawali pers 2016). [64]

${ }^{20}$ Hasra Wahyuni, 'Analisis Kedudukan Komisi Pemberantasan Korupsi (Kpk) Dalam Sistim Ketatanegaraan Repuplik Indonesia Menurut Undang-Undang Nomor 30 Tahun 2002' (Program Sarjana Universitas Islam Negeri Sultan Syarif Kasim Riau 2015).[47]. 
dalam melaksanakan tugas dan kewenangannya. ${ }^{21}$ Didalam Undang-Undang KPK sebelum perubahan juga disebutkan secara tegas bahwa KPK adalah lembaga Independen. Pada Pasal 3 Undang-Undang Nomor 30 Tahun 2002, menyatakan bahwa KPK adalah lembaga Negara yang bersifat independen dan bebas dari kekuasaan manapun dalam melaksanakan tugas dan wewenangnya. Kekuasaan manapun dalam hal ini seperti yang dinyatakan dalam penjelasan Pasal 3 UndangUndang Nomor 30 Tahun 2002 adalah kekuatan yang dapat mempengaruhi tugas dan wewenang KPK atau anggota KPK secara individual dari pihak eksekutif, yudikatif, legislatif, serta pihak-pihak lain yang terkait dengan tindak pidana korupsi atau keadaan dan situasi ataupun dengan alasan apapun.

\section{Karakteristik Lembaga Negara Independen}

Berdasarkan pendapat Zainal Arifin Mochtar, Karakteristik dari lembaga negara independen adalah sebagai berikut: ${ }^{22}$

1. Lahirnya dan ditempatkan lembaga tersebut tidak menjadi bagian dari cabang kekuasaan manapun;

2. Proses pemilihan lembaga tersebut bukan melalui political oppointee melainkan melalui seleksi;

3. Proses pemilihan dan pemberhentian berdasarkan pada mekanisme yang ditentukan oleh undang-undang yang mendasarinya;

4. Kepemimpinan bersifat kolektif kolegial;

5. Memiliki kewenangan yang bersifat self regulated.

Berdasarkan dari konsep independen diatas, KPK sebelum dibentuknya Dewan Pengawas sudah memenuhi kriteria sebagai Lembaga Negara Independen. Berdasarkan dari karakteristik lembaga Negara independen diatas disebutkan bahwa suatu lembaga Negara independen lahir dan ditempatkan tidak berada dalam kekuasaan manapun, seperti dalam Pasal 3 Undang-Undang Nomor 30 Tahun 2002 menyatakan bahwa KPK bersifat independen dan bebas dari pengaruh kekuasaan manapun. Proses pemilihan lembaga tersebut bukan melalui political oppointee

${ }^{21}$ Tjokorda Gde Indraputra dan I Nyoman Bagiastra, 'Kedudukan Komisi Pemberantasan Korupsi sebagai lembaga Negara bantu (state auxiliary institutions)', (2014) 02 Journal Ilmu Hukum.[4].

22 Zainal arifin mochtar, Op. Cit.[64]. 
melainkan melalui seleksi, dalam hal ini pemilihan dari Pimpinan KPK dipilih oleh DPR yang diusulkan oleh presiden yang dibantu oleh Panitia Seleksi untuk melancarkan pemilihan dan penentuan calon Pimpinan KPK. Selain itu dalam Pasal 29 huruf 8, menyatakan bahwa persyaratan untuk menjadi Pimpinan KPK tidak menjadi pengurus salah satu partai politik. Proses pemilihan dan pemberhentian berdasarkan pada mekanisme yang ditentukan oleh undang-undang yang mendasarinya. Proses pembentukan dan pemberhentian Pimpinan dan anggota KPK diatur dalam UndangUndang Nomor 30 Tahun 2002, yang diatur pada Pasal 30 dan Pasal 31 serta mekanisme pemberhentian diatur dalam Pasal 32. Kepemimpinan bersifat kolektif kolegial. Dalam kepemimpinan KPK, Pimpinan KPK bekerja secara kolektif seperti yang disebutkan dalam Pasal 21 ayat (5) Undang-Undang Nomor 30 Tahun 2002. Serta memiliki kewenangan yang bersifat self regulated. KPK dalam ini memiliki kewenangan untuk mengatur dirinya sendiri.

\section{Status Independensi Dewan Pengawas Dalam Komisi Pemberantasan Korupsi}

Berdasarkan Pasal 37 E ayat (1) Undang-Undang Nomor 19 Tahun 2019 menyatakan bahwa, ketua dan anggota Dewan Pengawas diangkat dan ditetapkan oleh Presiden. Pembentukan Dewan Pengawas dikhawatirkan tidak independen karena diangkat dan ditetapkan oleh Presiden yang dikhawatirkan sebagai bentuk intervensi pemerintah terhadap proses hukum yang berjalan pada KPK. Suatu hal yang penting dalam lembaga negara independen adalah membangun sistem pengawasan. Dalam KPK sudah terdapat pengawasan internal yaitu adanya Deputi Pengawas Internal dan Pengaduan Masyarakat. Tugas dan fungsi bidang Pengawas Internal dan Pengaduan Masyarakat diatur lebih lanjut pada Pasal 47 ayat (4) Peraturan Komisi Pemberantasan Korupsi Nomor 03 Tahun 2018 Tentang Organisasi Dan Tata Kerja Komisi Pemberantasan Korupsi, yang salah satu fungsinya yaitu melaksanakan pelaksanaan pengawasan internal terhadap KPK agar sesuai dengan peraturan perundang-undangan dan kebijakan yang ditetapkan oleh Pimpinan.

Maka dari itu dipertanyakan independensi Dewan Pengawas karena sebelum dibentuknya Dewan Pengawas yang sebelumnya sudah ada pengawas internal 
dalam KPK. Dewan Pengawas KPK menjadi satu kesatuan organisasi KPK yang melekat bersama dengan Pimpinan KPK dan Pegawai KPK sesuai dengan Pasal 21 ayat (1), sehingga kelembagaan dan fungsinya tidak bersifat independen karena masih satu lembaga sehingga fungsi check and balances sangat diragukan. ${ }^{23}$

\section{Keberadaan Dewan Pengawas dalam Undang-Undang Nomor 19 Tahun 2019}

Dibentuknya Dewan Pengawas dalam Undang-Undang Nomor 19 Tahun 2019 menimbulkan pertentangan pendapat dari para ahli, pertentangan pendapat tersebut terdapat yang menyetujui dibentuknya Dewan Pengawas tetapi ada juga yang menolak adanya Dewan Pengawas.

Beberapa pendapat ahli yang menyutujui adanya Dewan Pengawas antara lain, Menteri Hukum dan Hak Asasi Manusia Yasonna H Laoly, ahli hukum tata Negara Yusril Ihza Mahendra, dan Guru Besar Fakultas Hukum Universitas Padjajaran, Prof. Romli Atmasasmita. Selain pendapat ahli yang menyetujui dibentuknya Dewan Pengawas, terdapat pendapat ahli yang menolak adanya Dewan Pengawas antara lain pendapat guru besar fakultas hukum universitas trisakti Andi Hamzah dan pegiat Anti Korupsi dari ICW, Tama S Langkun.

Berdasarkan pendapat Menteri Hukum dan Hak Asasi Manusia Yasonna H Laoly, Dewan Pengawas pada komisi pemberantasan korupsi diperlukan untuk menciptakan mekanisme check and balances. ${ }^{24}$ Berdasarkan teori pengawasan mekanisme check and balances ini diperlukan agar tidak adanya penyalahgunaan weweang yang dimilik oleh KPK. KPK sebagai lembaga superbody yang memiliki kewenangan yang besar jika tidak adanya pengawasan, akan cenderung koruptif. Sehingga diperlukan fungsi pengawasan untuk mekanisme saling control antara lembaga. Sebelum dibentuknya Dewan Pengawas, dalam KPK terdapat Bidang Pengawasan Internal Dan Pengaduan

\footnotetext{
${ }^{23}$ Agus Suntoro, Op.Cit. [35].

${ }^{24}$ Ihsanudin, 'Yasonna Sebut Dewan Pengawas untuk "Check and Balances" di KPK', (Nasional Kompas, 2019), <https://nasional.kompas.com/read/2019/09/09/13152521/yasonna-sebut-dewan-pengawas-untuk-check-and-balances-di-kpk?page=all>, accesed 29 November 2019.
} 
Masyarakat yang berfungsi untuk melaksanakan pengawasan internal. Dalam Pasal 47 ayat (4) Peraturan Komisi Pemberantasan Korupsi Nomor 03 Tahun 2018 Tentang Organisasi Dan Tata Kerja Komisi Pemberantasan Korupsi, yang salah satu fungsinya yaitu melaksanakan pelaksanaan pengawasan internal terhadap KPK agar sesuai dengan peraturan perundang-undangan dan kebijakan yang ditetapkan. Serta dalam Pasal 48 diatur lebih lanjut mengenai fungsi yang dilaksanakan oleh Direktorat Pengawasan Internal.

Berdasarkan pendapat ahli hukum tata Negara Yusril Ihza Mahendra, bahwa berdasarkan prinsip tata kelola pemerintahan, pengawasan diperlukann karena tidak ada satupun lembaga yang tidak bisa diawasi. ${ }^{25}$ Yang mana selanjutnya juga menyatakan pengawasan terhadap KPK selama ini secara tidak langsung pengawasan dilakukan oleh DPR, namun diperlukan Dewan Pengawas yang secara khusus mengawasi KPK secara internal. Diperlukan pengawasan internal untuk mengawasi kinerja KPK agar sesuai dengan fungsi dan kewenanganya, serta untuk memastikan tidak adanya penyalahgunaan wewenang oleh KPK. Berdasarkan pegiat Anti Korupsi dari ICW, Tama S Langkun berpendapat bahwa Dewan Pengawas tidak diperlukan karena telah terdapat pengawasan internal yang dilakukan oleh Direktorat Pengawasan Internal. ${ }^{26}$

Berdasarkan pendapat Guru Besar Fakultas Hukum Universitas Padjajaran, Prof. Romli Atmasasmita berpandangan bahwa Dewan Pengawas menjadi media pengawasan agar penyadapan yang dilakukan dapat terkontrol dengan mendapatkan izin dari Dewan Pengawas selain dari komisioner KPK. Berbeda dari pendapat dari Prof. Romli Atmasasmita, Berdasarkan pendapat guru besar fakultas hukum Universitas Trisakti Andi Hamzah, KPK tidak memerlukan adanya Dewan Pengawas, dengan adanya Dewan Pengawas membuat birokrasi pemberian

\footnotetext{
${ }^{25}$ Feri Agus Setyawan, 'Yusril Sebut KPK Perlu Dewan Pengawas', (CNN Indonesia, 2019), $<$ https://www.cnnindonesia.com/nasional/20190911180426-12-429585/yusril-sebut-kpk-perlu-dewan-pengawas $>$, accesed 29 November 2019.

${ }^{26}$ Satrio Widianto, 'Menimbang Urgensi Dewan Pengawas KPK', (Pikiran Rakyat, 2019), $<$ https://www.pikiran-rakyat.com/nasional/pr-01319127/menimbang-urgensi-dewan-pengawas-kpk?page $=2>$, accesed 7 April 2020 .
} 
izin berubah menjadi panjang, selain itu juga menambah anggaran Negara di saat pemerintah sedang melakukan penghematan penggunaan anggaran. ${ }^{27}$

Dari pendapat ahli diatas, dibentuknya Dewan Pengawas pada komisi pemberantasan korupsi diperlukan untuk menciptakan mekanisme check and balances. Dibentuknya Dewan pengawas yang secara khusus diharapkan bisa mengawasi KPK secara internal agar tidak ada penyalahgunaan wewenang oleh KPK. Serta dengan adanya Dewan Pengawas dapat menjadi media pengawasan agar penyadapan yang dilakukan dapat terkontrol.

Berdasarkan Pasal 37 B huruf b Undang-Undang Nomor 19 Tahun 2019, Dewan Pengawas memiliki kewenangan untuk memberikan izin atau tidak memberikan izin penyadapan, penggeledahan dan/ataupenyitaan. Hal tersebut diluar sistem pengawasan karena Dewan Pengawas bukanlah aparat penegak hukum, dan yang memiliki kewenangan pro justitia tersebut adalah aparat penegak hukum. Pro justitia dalam hal ini adalah tindakan hukum yang diambil oleh aparat penegak hukum dalam proses penyelidikan dan penyidikan. ${ }^{28}$ Dewan pengawas yang bukan penegak hukum memiliki kewenangan pro justitia tetapi kewenangan pimpinan KPK sebagai penyidik dan penuntut dicabut oleh Undang-Undang.

Dalam pasal tersebut untuk melakukan penyadapan harus mendapat izin dari Dewan Pengawas. Berdasarkan Putusan Mahkamah Konstitusi dalam Perkara Nomor 006/PUU-I/2003 dan Nomor 012-016-019/PUU-IV/2006, Mahkamah Konstitusi menyatakan yang pada intinya bahwa kewenangan penyadapan KPK tidak melanggar konstitusi sehingga perlu dipertahankan dan selama ini kewenangan penyadapan sangat mendukung keberhasilan KPK dalam pemberantasan korupsi. Jika dilihat secara hukum KPK memiliki kewenangan melakukan penyadapan berdasarkan undang-undang yang berbasis pada evaluasi/ audit proses penyadapan, sehingga ketika KPK melakukan

\footnotetext{
${ }^{27}$ RFQ, 'Dua Professor Hukum Pidana Beda Pandangan Soal Dewan Pengawas KPK', (Hukum Online, 2016), <https://www.hukumonline.com/berita/baca/lt56b9d64245b97/dua-profesor-hukum-pidana-beda-pandangan-soal-dewan-pengawas-kpk/>, accesed 29 November 2019.

${ }^{28}$ Arif Maulana, 'Apa itu pro justitia?' (Hukum Online, 2019), <https://www.hukumonline. com/klinik/detail/ulasan/lt5e006f96d6231/apa-itu-ipro-justitia-i/>, accesed 24 Desember 2020.arif
} 
penyadapan tidak diperlukan adanya izin dari pengadilan. KPK menyatakan bahwa dalam melakukan penyadapan menggunakan mekanisme berdasarkan Standard Operational Procedure (SOP) yang ketat dan diaudit secara berkala oleh Kementerian Komunikasi dan Informatika.

Berdasarkan perkembangan dari Undang-Undang Nomor 19 Tahun 2019, telah diajukan permohonan uji materi oleh mahasiswa. Putusan Nomor 57/PUUXVII/2019 ini menyatakan permohonan para pemohon tidak diterima. Permohonan tersebut tidak diterima dikarenakan salah object (error in objecto). Yang seharusnya diajukan Undang-Undang Nomor 19 Tahun 2019 tetapi yang diajukan permohonan uji materi Undang-Undang Nomor 16 Tahun 2019.

Dari pembahasan pada bab ini, urgensi kebutuhan akan Dewan pengawas yang dimasukkakn dalam Undang-Undang KPK tidak didukung oleh alasan yang kuat, namun organ ini sudah menjadi bagian yang tidak terpisahkan dalam tubuh KPK. Independensi dari Dewan Pengawas sendiri juga menjadi pertanyaan karena pasca diundangkannya Undang-UndangNomor 19 Tahun 2019, KPK menjadi rumpun eksekutif atau menjadi bagian kekuasaan tertentu.

\section{Kesimpulan}

Kewenangan Dewan Pengawas pada Pasal 37 B Undang-Undang Nomor 19 Tahun 2019 yaitu kewenangan Dewan Pengawas untuk mengawasi KPK, memberikan izin penyadapan, penggeledahan dan penyitaan, menyusun dan menetapkan kode etik, menyelenggarakan sidang dugaan pelanggaran kode etik dan melakukan evaluasi kerja Pimpinan dan Pegawai KPK. Dilihat dari kewenangannya, Pengawasan yang dilakukan oleh Dewan Pengawas bukan hanya sekedar pengawasan terhadap Kode etik dan evaluasi kinerja Pimpinan dan Pegawai KPK, tetapi Dewan Pengawas mempunyai kewenangan diluar sistem pengawasan, yaitu memiliki fungsi pro justitia. Fungsi pro justitia tersebut seharusnya diberikan oleh lembaga yang melakukan fungsi Pro Justitia yaitu Aparat Penegak Hukum dimana Dewan Pegawas bukan sebagai bagian dari penegakan hukum dalam criminal justice system. 
Dewan Pengawas KPK menjadi satu kesatuan organisasi KPK yang melekat bersama dengan Pimpinan KPK dan Pegawai KPK sesuai dengan Pasal 21 ayat (1), sehingga kelembagaan dan fungsinya tidak bersifat independen karena masih satu lembaga sehingga tidak terpenuhinya prinsip check and balances.

\section{Daftar Bacaan}

\section{Buku}

Zainal arifin mochtar, Lembaga Negara Independen (Rajawali pers 2016).

Henry Campbell Black, Black's Law Dictionary With Pronunciations (ST. Paul, Minn, West Publishing Co, 1983).

Jimly Asshiddiqie, Pokok-Pokok Hukum Tata Negara Indonesia (BIP Kelompok Gramedia, 2008).

R Widyo Purmono, Pemberantasan Korupsi Dan Pidana Lainnya (Kompas Media Nusantara, 2016).

\section{Jurnal}

Josef M. Monteiro, 'Penempatan Komisi Pemberantasan Korupsi Sebagai Organ Undang-Undang Dasar Negara RI Tahun 1945' (2012) 02 Jurnal Hukum Dan Pembangunan.

Agus Suntoro, 'Penyadapan Dan Eksistensi Dewan Pengawas Komisi Pemberantasan Tindak Pidana Korupsi’ (2020) 17 Jurnal Legislasi Indonesia.

Hendra N urtjahjo, 'Lembaga, Badan, Dan Komisi Negara Independen (State Auxiliary Agencies) Di Indonesia: Tinjauan Hukum Tata Negara' (2005) 35 Jurnal Hukum Dan Pembangunan.

Tjokorda Gde Indraputra dan I Nyoman Bagiastra, 'Kedudukan Komisi Pemberantasan Korupsi sebagai lembaga Negara bantu (state auxiliary institutions)' (2014) 02 Journal Ilmu Hukum.

\section{Laman}

Aida Mardatillah, 'Kewenangan Dewan Pengawas KPK Disebut Lampaui Batas Pengawasan', (Hukum Online, 2019) <https://www.hukumonline.com/berita/ baca/lt5daea72d91232/kewenangan-dewan-pengawas-kpk-disebut-lampauibatas-pengawasan/> accessed 16 November 2019. 
Arif Maulana, 'Apa itu pro justitia?' (Hukum Online, 2019), <https://www. hukumonline.com/klinik/detail/ulasan/lt5e006f96d6231/apa-itu-iprojustitia-i/> accesed 24 Desember 2020.

Andry Novellino, 'Dewan Pengawas Dan Segudang Curiga Intervensi Pada KPK', (CNN Indonesia, 2019), <Https:/Www.Cnnindonesia.Com/ Nasional/20190920204301-32-432456/Dewan-Pengawas-Dan-SegudangCuriga-Intervensi-Pada-Kpk>, accesed 29 Maret 2020.

Fahmi Ramadhan Firdaus, 'Keberadaan KPK dalam Upaya Pemberantasan Korupsi', (Hukum Online, 2019), <https://www.hukumonline.com/klinik/detail/ulasan/ 1t5ca466cb7f8ed/keberadaan-kpk-dalam-upaya-pemberantasan-korupsi/> , accesed 9 Januari 2020.

Satrio Widianto, 'Menimbang Urgensi Dewan Pengawas KPK', (Pikiran Rakyat, 2019), <https://www.pikiran-rakyat.com/nasional/pr-01319127/menimbangurgensi-dewan-pengawas-kpk?page $=2>$ accesed 7 April 2020.

RFQ, 'Dua Professor Hukum Pidana Beda Pandangan Soal Dewan Pengawas KPK', (Hukum Online, 2016), <https://www.hukumonline.com/berita/baca/ 1t56b9d64245b97/dua-profesor-hukum-pidana-beda-pandangan-soal-dewanpengawas-kpk/>, accesed 29 November 2019.

Ihsanudin, 'Yasonna Sebut Dewan Pengawas untuk "Check and Balances" di KPK', (Nasional Kompas, 2019), <https://nasional.kompas.com/ $\mathrm{read} / 2019 / 09 / 09 / 13152521 /$ yasonna-sebut-dewan-pengawas-untuk-checkand-balances-di-kpk?page=all $>$ accesed 29 November 2019.

Feri Agus Setyawan, 'Yusril Sebut KPK Perlu Dewan Pengawas', (CNN Indonesia, 2019), <https://www.cnnindonesia.com/ nasional/20190911180426-12-429585/yusril-sebut-kpk-perlu-dewanpengawas $>$ accesed 29 November 2019.

\section{Skripsi}

Aulia Rahmat, 'Urgensi Pengawasan Terhadap Komisi Pemberantasan Korupsi Republik Indonesia Dalam Struktur Ketatanegaraan Indonesia' (Program Sarjana Universitas Islam Indonesia 2018).

Hasra Wahyuni, 'Analisis Kedudukan Komisi Pemberantasan Korupsi (KPK) Dalam Sistim Ketatanegaraan Repuplik Indonesia Menurut Undang-Undang Nomor 30 Tahun 2002' (Program Sarjana Universitas Islam Negeri Sultan Syarif Kasim Riau 2015).

Tomi Marlin Manday, 'Studi Konseptual Mengenai Badan Pengawas Komisi 

Cris Septiani: Dewan Pengawas Dalam...

Pemberantasan Korupsi' (Program Sarjana Universitas Islam Negeri Syarif Hidayatullah Jakarta, Jakarta 2018).

\section{Perundang-undangan}

Undang-Undang Nomor 19 Tahun 2019 tentang Perubahan Kedua Atas UndangUndang Nomor 30 Tahun 2002tentang Komis Pemberantasan Tindak Pidana Korupsi. 